JURNAL RESPIRASI

JR

Vol. 3 No. 1 Januari 2017

\title{
Problema Diagnostik dan Respons Kemoterapi pada Seorang Penderita Classical Limfoma Hodgkin Tipe Mixed Cellularity dengan Temporary Spontaneus Regression
}

Daniel Maranatha, Bintang Bestari

Departemen Pulmonologi dan Ilmu Kedokteran Respirasi, Fakultas Kedokteran Universitas Airlangga/RSUD Dr. Soetomo

\begin{abstract}
Background: Mixed cellularity classical hodgkin lymphoma $(M C C H L)$ is the secound subtype of classical hodgkin lymphoma (cHL) which often happens. MCCHL is aggressive but has a relatively high recovery rate. The diagnosis of cHL is sometimes difficult. Spontaneous regression can occur in $\mathrm{CHL}$ but is very rare, temporary or permanent. CHL including diseases with a fairly high cure rate, about $80 \%$ of patients recover with first-line chemotherapy. Case: Male age 26 years, 9 months cough, shortness of breath, chest pain 8 months, 6 months fever disappear with enlargement of right supraclavicular lymph nodes appearing at 11 days before admission. Chest $X$-ray shows the presence of mediastinal mass supported by contrast thoracic CT scan. FNAB has been done three times with no meaningful results. In one of the chest radiographs and CT scan of the thoracic with contrast evaluation showed a reduction in tumor size. Open thoracotomy biopsy is performed with Hodgkin's lymphoma results. On immunohistochemical examination obtained MCCHL. Chemotherapy with $A B V D$ regimen was administered for three cycles with partial remission and was continued with 6 cycles with stable disease outcomes. Conclusion: Spontaneous temporary regression in cases with mediastinal tumor suspicion may occur in cHL and may cause difficulties in diagnosing. Open biopsy is required as a gold standard and has to be supported by immunohistochemical test. First-line chemotherapy response in $\mathrm{cHL}$ is good.
\end{abstract}

Keywords: hodgkin's lymphoma, mixed cellularity classical hodgkin lymphoma, diagnostic problems, spontaneous temporary regression, chemotherapy response

Correspondence: Daniel Maranatha, Departemen Pulmonologi dan Ilmu Kedokteran Respirasi, Fakultas Kedokteran Universitas Airlangga/RSUD Dr. Soetomo. Jl. Mayjen. Prof. Dr. Moestopo 6-8 Surabaya 60286. E-mail: dmaranatha@ hotmail.com

\section{PENDAHULUAN}

Limfoma Hodgkin (LH) merupakan tumor ganas dari sistem limfatik namun dapat disembuhkan. Ini pertama kali ditemukan oleh Thomas Hodgkin pada tahun 1832. Insiden LH bervariasi tergantung usia, jenis kelamin, ras, geografis, kelas sosial dan subtipe histologis. Asia mempunyai angka insiden yang terendah (5,5/100.000 orang di Yaman dan Lebanon, < 1/100.000 orang di Cina dan Jepang). Angka kematian juga tergolong rendah karena mempunyai respons yang baik terhadap terapi. ${ }^{1}$

Limfoma Hodgkin dapat diklasifikasikan menjadi 2 kelompok yaitu classical Hodgkin Lymphoma (cHL) dan nodular lymphocyte predominant hodgkin Lymphoma (NLPHL). cHL dibagi lagi menjadi 4 subtipe yaitu nodular sclerosis, mixed cellularity, lymphocyte-depleted dan lymphocyte-rich classical. ${ }^{2}$

Mixed cellularity classical hodgkin lymphoma (MCCHL) merupakan subtipe cHL kedua yang sering terjadi dengan frekuensi sebesar 10-20\%. MCCHL umumnya terjadi pada usia lanjut (55-74 tahun) atau anak-anak (0-14 tahun). MCCHL juga bersifat agresif namun dapat disembuhkan. Regresi spontan dapat terjadi pada Classical Lymphoma Hodgkin (cHL) namun sangat jarang. Regresi spontan dapat terjadi sementara atau permanen. Dari 16 kasus regresi spontan pada cHL, 5 di antaranya merupakan mixed cellular type namun belum pernah ada laporan kasus regresi spontan sementara yang terjadi pada $\mathrm{cHL} .{ }^{3}$

CHL mudah untuk dikenali terutama pada subtipe nodular sklerosis. Pada MCCHL mudah dikenali jika 
pada sediaan ditemukan eosinofil dengan sel ReedSternberg (R-S). Diagnosis menjadi sulit jika sel R-S hanya sedikit didapat. ${ }^{3}$ CHL termasuk penyakit dengan angka kesembuhan yang cukup tinggi, sekitar $80 \%$ penderita sembuh dengan kemoterapi lini pertama. ${ }^{4}$

Berikut ini dilaporkan suatu kasus problem diagnostik dan respons kemoterapi seorang penderita Classical Limfoma Hodgkin Mixed Cellularity Type dengan temporary spontaneus regression.

\section{KASUS}

Seorang laki-laki usia 26 tahun dengan keluhan utama batuk. Batuk 9 bulan hilang timbul, dahak berwarna putih kental sulit dikeluarkan, nyeri dada sebelah kanan 8 bulan, panas naik turun selama 6 bulan, sesak nafas 1 bulan, keringat malam dan nafsu makan menurun. Benjolan di leher kiri timbul 1 hari sebelum masuk rumah sakit.

Pada pemeriksaan fisik didapatkan pembesaran kelenjar getah bening di supraclavicula kiri berukuran $0,5 \times 0,5$ $\mathrm{cm}$, kenyal lunak. Pergerakan dada asimetris, dada kanan tertinggal, fremitus raba menurun di $2 / 3$ bawah paru kanan. Perkusi redup pada $2 / 3$ bawah paru kanan, suara nafas vesikuler menurun pada 2/3 lapangan paru kanan bawah.

Hasil Laboratorium didapatkan hemoglobin 9,8 g/dl, leukosit 11.490/ $\mathrm{L}$, trombosit $441.000 / \mu \mathrm{L}$, laktat dehidrogenase 816 . Pada beberapa foto toraks didapatkan massa mediastinum anterior-medius (gambar 1 dan 2). Pada CT scan toraks dengan kontras didapatkan enhancing solid mass lobulated di mediastinum anterior menyokong gambaran massa mediastinum anterior (gambar 3 dan 4). Pada salah satu foto toraks dan CT scan toraks dengan kontras evaluasi menunjukkan adanya pengecilan ukuran tumor dari ukuran +/- 9,27 × 5,74 × 9,15 cm (19 Juni
2014) menjadi +/- 5,1 × 6,7 × 8,3 cm (14 November 2014) namun didapatkan efusi pleura.

Beberapa kali pemeriksaan histopatologi spesimen yang didapat dari sputum, cairan pleura maupun Fine Needle Aspiration Biopsy tidak didapatkan hasil yang representatif dan lebih mengarah ke Spindle Cell Mesenchymal Tumor hingga diputuskan untuk dilakukan open biopsi torakotomi. Pada pemeriksaan histopatologi spesimen yang didapat dari open biopsi didapatkan kesimpulan berupa Limfoma Hodgkin (gambar 5). Setelah itu kami lanjutkan pemeriksaan imunohistokimia pada spesimen tersebut didapatkan CD 30, Ki-67 dan Pax-5 positif sedangkan CD 20, CD 3 dan TIA-1 negatif (gambar 6 dan 7).

Berdasarkan anamnesis, pemeriksaan fisik, hasil operasi dan semua hasil pemeriksaan penunjang (pada perbandingan foto toraks bulan Juni dan Oktober 2014 serta Ct scan toraks dengan kontras bulan Juni dan November 2014 yang memperlihatkan ukuran tumor mengecil dari ukuran 9,27×5,74 ×9,15 cm menjadi 5,1 ×6,7×8,3 $\mathrm{cm}$ namun didapatkan efusi pleura), maka kami diagnosis pasien ini dengan Limfoma Hodgkin tipe mixed cellularity stadium IVB dengan temporary spontaneous regression.

Setelah diagnosa dapat ditegakkan, pemberian kemoterapi dengan regimen ABVD diberikan. Pada kasus ini termasuk partial remission setelah pemberian 3 siklus kemoterapi ABVD tampak pada pemeriksaan CT scan toraks awal sebelum terapi massa mediastinum anterior medius ukuran $5,1 \times 6,7 \times 8,3 \mathrm{~cm}$ menjadi $3,9 \times 5,9 \times 2,4 \mathrm{~cm}$ (gambar 8). Keluhan batuk dan demam juga menghilang. Namun setelah dilanjutkan kemoterapi ABVD hingga siklus ke 6, respons penderita menjadi stable disease. Pada MSCT toraks terakhir ukuran tumor menjadi $3,4 \times 4,27 \times 3,78 \mathrm{~cm}$ (gambar 9). Pada saat pemberian kemoterapi didapatkan beberapa efek samping seperti mual, muntah, leukopenia namun masih dapat ditolerir dan diatasi.
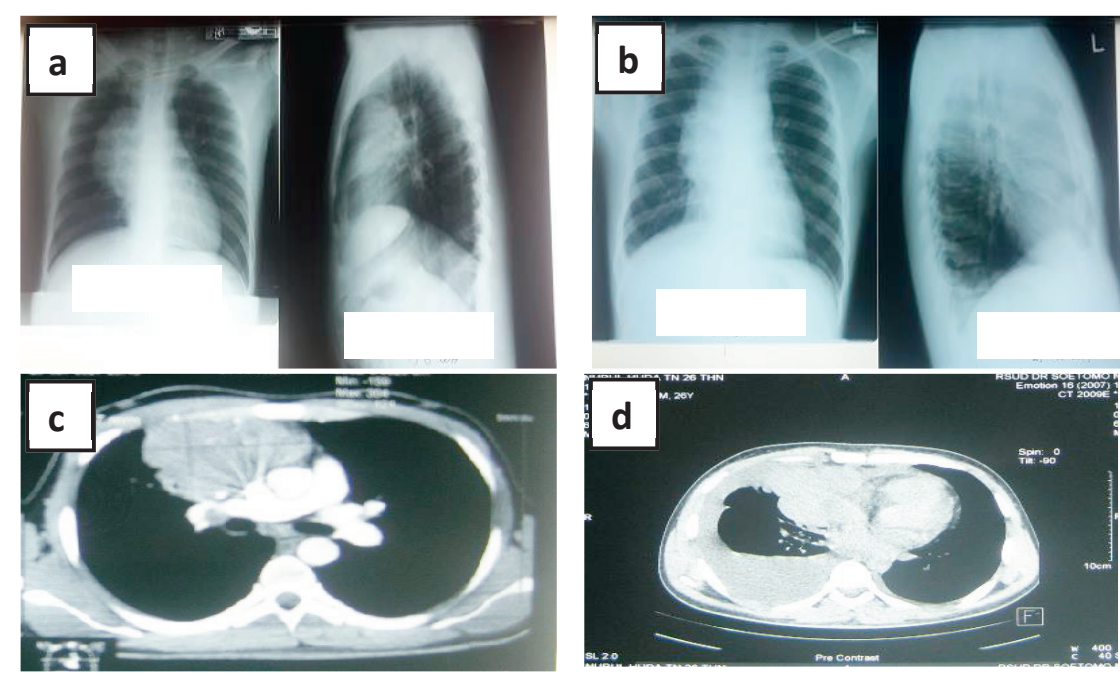

Gambar 1. a). Foto toraks tanggal 13 Juni 2016; b). Foto toraks tanggal 27 Oktober 2016; c). CT scan toraks tanggal 19 Juni 2014; d). CT toraks tanggal 14 November 2014 

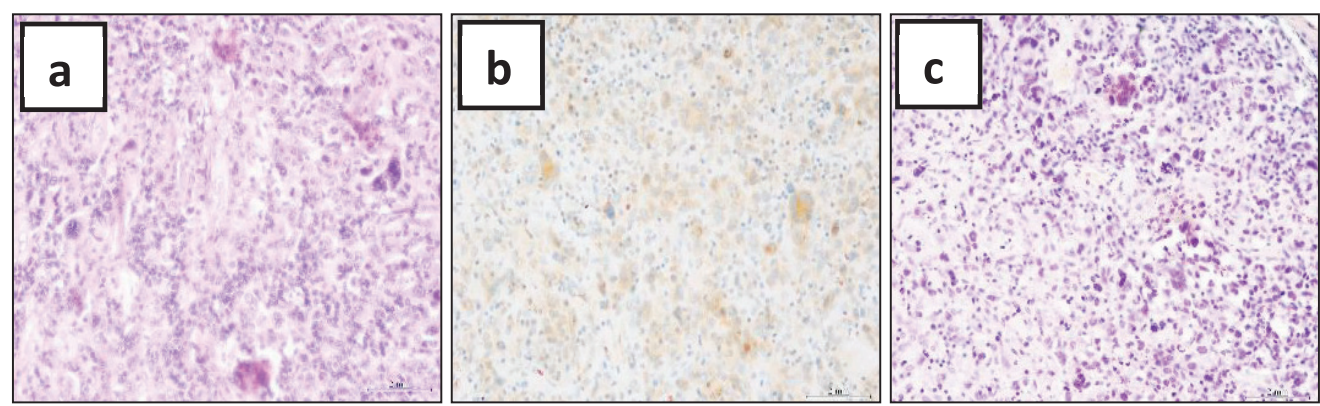

Gambar 2. a) Pemeriksaan histopatologi dari spesimen open biopsi torakotomi; b) Pemeriksaan imunohistokimia (CD 30 dan Ki 67 positif); c) Pemeriksaan imunohistokimia (Pax 5 positif)
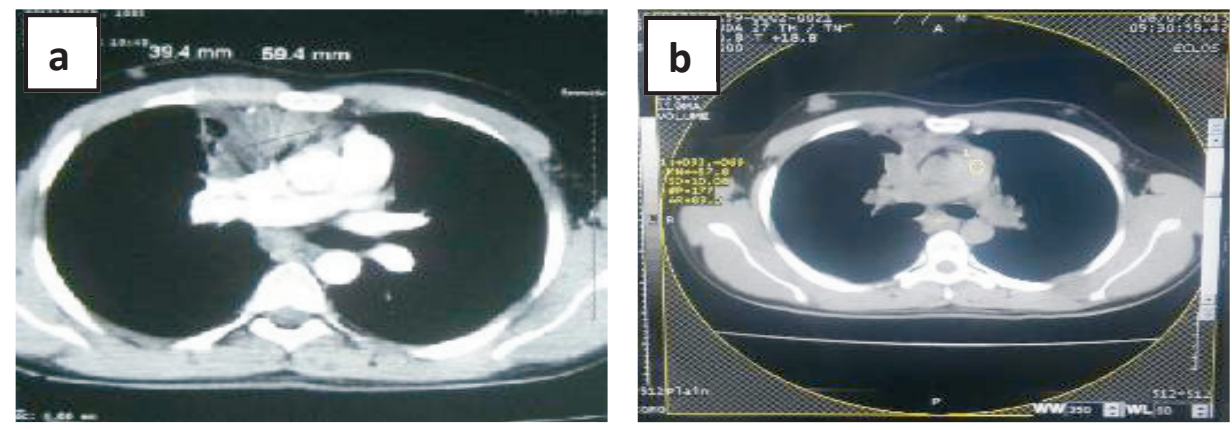

Gambar 3. a) CT scan toraks post kemoterapi ABVD siklus III; b) CT scan toraks post kemoterapi ABVD siklus VI

\section{DISKUSI}

Limfoma Hodgkin merupakan keganasan kelenjar limfa yang berasal dari sel B. Penyakit ini lebih sering terjadi pada usia muda sekitar 20-35 tahun. Angka insiden di negara maju lebih tinggi, rendah di Asia dan umumnya pada laki-laki. 5-years survival rate sekitar $80 \%$ pada pasien yang advanced dan $90 \%$ pada limited stage disease Mixed cellularity Hodgkin Lymphoma (MCCHL) merupakan tipe kedua yang umum terjadi dengan insiden sekitar $15-30 \% .5 .6$

Gejala klinis Limfoma Hodgkin tidak spesifik. Penderita yang didiagnosa Limfoma Hodgkin sebesar $75 \%$ tidak menunjukkan gejala. Gejala awal dari penyakit ini disebut B Symptoms dapat ditemukan pada penyakit lain seperti demam (hilang timbul dalam beberapa hari atau minggu), tanpa infeksi, keringat malam basah dan penurunan berat badan (umumnya $>10 \%$ berat badan normal) dalam 6 bulan. ${ }^{6}$

Gold Standart diagnosis Limfoma Hodgkin adalah biopsi jaringan dan didukung oleh pemeriksaan imunohistokimia (metode untuk mendeteksi keberadaan antigen spesifik di dalam sel suatu jaringan dengan menggunakan prinsip pengikatan antara antibodi $(\mathrm{Ab})$ dan antigen (Ag) pada jaringan hidup). Pemeriksaan imunohistokimia yang umumnya dilakukan untuk mendiagnosis Limfoma Hodgkin terdapat pada tabel $1 .^{6}$
Sejak tahun 1990an, penggunaan biopsi jarum halus sebagai salah satu teknik untuk diagnosis dini limfoma meningkat. Pada penelitian yang dilakukan oleh Wendy et al dengan 68 pasien mengatakan bahwa FineNeedle Aspiration Biopsy (FNAB) memiliki sensitivitas $86,2 \% .{ }^{7}$ Hal ini didukung oleh penelitian yang dilakukan Covarrubias-Espinoza et al bahwa sensitivitas FNAB sekitar $87,5 \% .^{8}$ sedangkan Zhang et al yang menyatakan bahwa diagnostik akurasi FNAB untuk Limfoma Hodgkin sekitar $77,8 \% .^{9}$

Walaupun penggunaan biopsi jarum halus sebagai salah satu teknik diagnosis meningkat pesat, banyak klinisi yang menganggap kurang cukup kuat. Diagnosis definitif Limfoma Hodgkin sulit dengan hanya menggunakan FNA sendiri, bahkan menggunakan flow cytometri dan cell block IHC. Hal ini mungkin disebabkan cHL umumnya merupakan tumor sklerotik dan sel neoplasma hanya komponen kecil dari sampel yang umumnya sedikit. ${ }^{10}$

Penegakan diagnosis Limfoma Hodgkin memang tidak mudah dan rumit. Biopsi pertama terkadang tidak memberikan jawaban definitif dan dibutuhkan beberapa kali biopsi. Limfoma Hodgkin telah lama menjadi tantangan bagi dokter spesialis patologi anatomi karena mempunyai gambaran morfologis yang beragam. Pada satu sisi, Limfoma Hodgkin subtipe dapat dicurigai sebagai kondisi jinak termasuk hyperplasia follicular limphoid, progressive transformation of germinal centers (PTGCS), plasma cell 
Tabel 1. Pemeriksaan imunohistokimia pada Limfoma Hodgkin ${ }^{3}$

\begin{tabular}{lcc}
\hline & LP Cells NLPHL & HRS Cells CHL \\
\hline Nonlineage antigens & & - \\
CD45 & + & + \\
CD30 & & +- \\
CD15 & + & $-/+$ \\
\hline B cell-associated antigens & + & $-/+$ \\
CD20 & $+/-$ & - \\
CD79a & $+/-$ & - \\
J chain & & $+/-$ \\
IgD & + & $+/-$ \\
B cell-related transcription factors & + & - \\
BOB.1 & + & $+($ weak $)$ \\
OCT 2 & + & $+/-*$ \\
PU.1 & - & $+/-*$ \\
PAX5 & - & \\
\hline EBV detection & & \\
LMP-1 & & \\
EBER & & \\
\hline Often positive in MCCHL/LDCHL. Ussually negative in NSCHL. & \\
+ indicates positive in all cases; +/-, positive in majority of cases; + /-, positive in minority of cases; - \\
negative in all cases.
\end{tabular}

variant of castleman disease dan reaksi granulomatous sedangkan di sisi lain, mereka dapat menyerupai Limfoma Non Hodgkin, poorly differentiated carcinoma, malignant melanoma atau high grade sarcoma. ${ }^{11}$

Ada beberapa kesulitan yang umumnya dihadapi dalam mendiagnosa Limfoma Hodgkin. Pertama, potongan histologis terlalu tebal sehingga mengaburkan gambaran adanya Large Cells. Kedua, artefak pada spesimen biopsi seperti fiksasi yang kurang baik atau $a$ crush artifact yang umumnya terjadi pada spesimen yang didapat dari core, mediastinoscopic atau transbronchial biopsy. Ketiga, diagnosis histologi Limfoma Hodgkin sulit pada kasus yang mengandung sedikit sel reed-stenberg saat gambaran histologis menyerupai gambaran neoplasma jinak atau sel reed-stenberg berlimpah sehingga mirip neoplasma ganas yang lain. ${ }^{11}$

Pada kasus ini juga terjadi regresi spontan yang menambah kesulitan dalam mendiagnosis. Regresi spontan dari kanker adalah menghilangnya keseluruhan atau sebagian, sementara atau permanen dari penyakit keganasan, tanpa terapi atau dalam terapi namun dianggap tidak adekuat. Fenomena ini valid namun sangat jarang dan telah diteliti sepanjang sejarah ilmu kedokteran. ${ }^{12}$ Frekuensi terjadinya regresi spontan pada kanker diestimasi sekitar 1 kasus per 100.000 pasien. Regresi spontan umumnya terjadi pada hypernephroma, melanoma, neuroblastoma, leukemia, dan non-Hodgkin Lymphoma. ${ }^{13,14}$

Regresi spontan dapat terjadi pada Classical Lymphoma Hodgkin (cHL) namun sangat jarang. Dari 16 kasus regresi spontan pada $\mathrm{cHL}, 5$ di antaranya merupakan mixed cellularity type namun belum pernah ada laporan kasus regresi spontan sementara yang terjadi pada cHL. Penyebab terjadinya regresi spontan masih belum dapat dijelaskan. ${ }^{14,15}$ Beberapa mekanisme yang dapat diterima penyebab terjadinya regresi spontan yaitu respons imun sitotoksik, Instabilitas genetic, apoptosis, sitokin, Tumor Supressor Genes, hipoksia dan stress ${ }^{15}$

Sembuh adalah tujuan dari terapi pada pasien Limfoma Hodgkin. Pasien Limfoma Hodgkin yang dapat disembuhkan dengan pendekatan terapi yang tepat sebesar $75 \%$. Angka kesembuhan lebih tinggi mencapai sekitar $90 \%$ pada pasien usia muda dan masih dalam tahap awal penyakit. Pendekatan terapi untuk Limfoma Hodgkin dapat dilihat pada tabel 2

Ada beberapa kriteria untuk menilai respons terapi pada Limfoma Hodgkin yaitu:

Complete Remission (CR) : Semua gejala dan tanda menghilang setelah pemberian terapi.

Cure

: Semua gejala dan tanda Limfoma tidak muncul setelah bertahuntahun dalam continuous, complete remission

Disease Progression : Penyakit memburuk atau tumor membesar saat terapi diberikan.

Partial remission $(P R) \quad$ : Ukuran tumor mengecil hingga $1 / 2$ ukuran sebelum diberikan terapi. 
Improvement

Stable disease

Refractory disease

Relapse

\section{KESIMPULAN}

Telah dilaporkan sebuah kasus problema diagnostik dan respons kemoterapi pada seorang pria dengan Limfoma Hodgkin stadium IVB tipe mixed cellularity yang sempat mengalami regresi spontan namun bersifat sementara saat belum terdiagnosa pasti, gambaran patologi anatomi berupa Limfoma Hodgkin, pada pemeriksaan imunohistokimia didapatkan CD 30, Ki-67 dan Pax-5 positif. Telah dilakukan pemberian kemoterapi ABVD sebagai terapi lini pertama dengan hasil didapatkan perbaikan gejala klinis, radiologis dan kualitas hidup penderita dengan efek samping yang dapat ditolerir oleh penderita. ABVD telah diberikan sebanyak 3 kali dengan hasil keseluruhan partial remission yang ditandai dengan gambaran radiologis gambaran massa mediastinum anterior medius mengecil lebih dari setengah ukuran awal pada ulangan CT Scan toraks. Namun setelah dilanjutkan kemoterapi ABVD hingga siklus ke 6, respons penderita menjadi stable disease.

\section{DAFTAR PUSTAKA}

1. Al-Tonbary, Y. Epidemiology of hodgkin's lymphoma, hodgkin's lymphoma, Dr. Nima Rezaei (Ed.), ISBN: 978-953-51-0402-5, InTech, (2012) Available from: http://www.intechopen.com/books/ hodgkin-slymphoma/epidemiology-of-hodgkin-s-lymphoma

2. Leukemia and Lymphoma Society. Hodgkin lymphoma. Leukemia and Lymphoma Society. 2013; 1-44

3. Eberle FC, Mani H, Jaffe, ES. Histopathology of hodgkin's lymphoma. Cancer J 2009;15: 129-137.

4. Derenzini E, Younes A. Predicting treatment outcome in classical hodgkin lymphoma: genomic advances. Genome Medicine. 2011(3);26: 1-13.

5. Union for International Cancer Control. Hodgkin lymphoma(adult) in review of cancer medicines on the WHO list of essential medicines. Union for International Cancer Control. 2014; 1-9.

6. American Cancer Society. Hodgkin disease. American Cancer Society. 2014. Available from: www.cancer.org

7. Wendy S, Moreland. MD, Kim R. Utility and outcomes of fine-needle aspiration biopsy in Hodgkin's disease. Diagnostic cytopathology. 2002;26(5): 278-282.

8. Covarrubias-Espinoza. G, Rivera-Gomez R, Rendon-Garcia H. The use of imprint and fine needle aspiration biopsy in early malignancy diagnosis. Bol Clin Hosp Infant Edo Son. 2012;29(2): 53-57.

9. Zhang S, Yu X, Zheng Y, Xie J, Zhou X. Value of fine needle aspiration cell blocks in the diagnosis and classification of lymphoma. Int J Clin Exp Pathol. 2014;7(11): 7717-7725.

10. Mayall F, Darlington A, Harrison B, Fine needle aspiration cytology in the diagnosis of uncommon types of lymphoma. J Clin Pathol. 2013;56: 821-825.

11. Listinsky CM. A practical approach to the diagnosis of Hodgkin Lymphoma. Am J Clin Pathol. 2002;117: 76-94.

12. Kappauf HW. Spontaneous remission of cancer-enigma and paradigm Onkologie. 2006:29: 129-130.

13. Mohsen A, Ghanem H, El-Bayoumi J, Tabbara I. Spontaneous regression of classical hodgkin lymphoma: A case report and review of the literature. Clinical Advanced in Hematology \& Oncology. 2012;10: 763-764.

14. Thirukonda V, Petrich A, Parekh S. Classical hodgkin lymphoma and spontaneus regression. Clinical Advanced in Hematology \& Oncology. 2012;10: 765-766.

15. Oluwole O, Samaila M. Spontaneus tumour regression. The Internet Journal of Pathology. 2005;8(1): 1-4.

16. Lymphoma Research Foundation. Understanding hodgkin lymphoma: A guide for patients, survivors and loved ones $3^{\text {rd }}$ ed. Lymphoma Research Foundation. 2009; 1-107. 